\title{
Influence Of Project Planning Strategy On Implementation of Energy Access Projects In Underserved Counties In Kenya
}

\author{
Evans Kituzi Avedi \\ PhD Candidate, School of Open and Distance Learning, \\ University of Nairobi, Kenya \\ Dr. Angeline Sabina Mulwa \\ Lecturer School of Open and Distance Learning, \\ University of Nairobi, Kenya; \\ Prof. Dorothy Ndunge Kyalo \\ Senior Lecturer, School of Open and Distance Learning, \\ University of Nairobi, Kenya
}

\begin{abstract}
The purpose of this article was to examine the extent to which project planning influence implementation of rural energy access projects in underserved counties in Kenya. The unit of analysis was households, commercial centers, schools, hospitals and a sample size of 373 respondents was selected from a target population of 5,604 respondents in areas where rural electrification has been implemented in underserved counties in Kenya through stratified sampling and purposive sampling techniques. Data was collected from the respondents through questionnaires, interviews and observation. The research outcome depicted that project planning had significant influence on the implementation of energy access projects in underserved counties in Kenya. The coefficient of determination $\mathbf{R}^{2}$ was 0.042 and it depicted that project planning explained $4.2 \%$ of variations in implementation of energy access projects in underserved counties in Kenya. The remaining $\mathbf{9 5 . 8 \%}$ of variations in implementation of energy access projects in underserved counties remained unexplained and were explained by other variables other than project planning that were not captured in this model. The overall F statistic of $F=4.399(p=0.05)$ was statistically significant at $P=0.000<0.05$ hence was suitable to measure project planning. This study found out that while each country has its own priorities and needs, many have invested in policy reforms and capacity building, mainstreamed energy access within development programs, and used various incentive-based instruments to catalyze finance for energy access markets.
\end{abstract}

Keywords: Access to Energy, Project Planning, Project Implementation, Rural Electrification, Underserved Counties 
Avedi, E. K., Mulwa, A. S., \& Kyalo, D. N. (2020) Influence Of Project Planning Strategy On Implementation Of Energy Access Projects In Underserved Counties In Kenya. Advances in Social Sciences Research Journal, 7(4) 335-350.

\section{INTRODUCTION}

Project Planning is a discipline for stating how to complete a project within a certain timeframe, usually with defined stages and with designated resources. Project planning in the current article means efforts by the government to promote general economic fairness through regulation, policy formulation and even subsidies in the energy access sector. The project implementation evaluation report by the African Development Bank (AfDB, 2012) revealed that the key challenges facing Africa's power sector are inadequate generation capacity, limited electrification, low power consumption, unreliable services, high costs, and a financing gap of approximately $\$ 23$ billion a year. Policy and regulatory challenges which pertains to lack of long-term sectoral vision, planning and political prioritization to make it happen, financing challenges that relates to payment risk, coupled with lack of risk mitigation tools and inadequate financing support (grants, loans, grace periods and long term interest rates) makes it difficult to secure finance for rural energy projects, market development challenges due to lack the of innovative business models, local market knowledge and resource availability to implement rural energy solutions, technical and structural challenges as a result of insufficient base load, lack of pilot demonstration projects, poor grid conditions (or complete unavailability of the grid) leads to higher costs and inadequate design solutions and information and capacity challenges caused by lack of knowledge on available technologies, lack of capacity to design, manage, and operate coupled with limited local involvement and public support (Wamukonya,2013). These challenges call for a paradigm shift in the development of the energy sector strategies that seeks to use the vast renewable resources of the continent. In energy access projects, different activities are involved and hence the need for proper project planning and management to ensure that materials and works are procured and supplied within schedule.

\section{Statement of the Problem}

It is unfortunate that only 290 million people out of 915 million in the sub-Saharan Africa have access to electricity. This is in spite of the fact that the number of the people who do not have access to electricity keeps on rising every year. To make the matter worse, about 80 percent of the people without electricity are in rural areas; most of which are remote. This is an important element when considering how these people would access electricity (IEA, 2014). Kenya being part of Africa faces this challenge because only about 46 percent of the population has access to electricity (2015) which means that majority of the people rely on conventional fuels: kerosene, charcoal and firewood. About 1.2 million of the people living in 14 underserved counties in the country do not have access to electricity in their households (Republic of Kenya, 2013). Beside even though the 14 counties account for about 72 percent of national land mass and 20 percent of national population, access to energy in these counties is still very low compared to other counties in Kenya. Failures of completion of energy access projects within quality, time and budget in underserved counties has resulted in these areas remaining economically underdeveloped. The implementation of rural electricity programs has been a challenge to the government because only $36 \%$ of the people living in rural areas have access to electricity.

Most of the studies that have conducted in the past have focused their attention on identifying factors affecting rural electrification with most researchers addressing themselves to the roles that governments play in driving rural electrification. In spite of this, very few of these studies have addressed themselves to funding mechanisms, legislative frameworks and institutional factors that support the implementation of access to energy strategies and policies (Maithani and Gupta, 2015). In energy access projects, various key players in energy sector are set up with each player having a 
distinct role to ensure they deliver project objectives. These energy stakeholders work within a mix of skills and judgment and their differences manifest while exercising their skills and judgement during project implementation which further leads to huge disparities in time, cost and quality overruns during project implementation.

Most of the underserved counties in the country do not have good road networks, water systems, access to electricity and other social services. The unfortunate thing is that most of the people living in these areas were originally nomads who relied heavily on pastoralist activities. In addition, the regions have low population densities thereby it becomes almost difficult to offer public services to these people. Furthermore, there is high level of insecurity that undermines economic development in some of those regions (Republic of Kenya, 2013). Because of the unique challenges that low population density, underdeveloped rural economies and low demand for energy in these regions, there is need to develop strategies that would address themselves to the special conditions of the underserved counties in the country. Some of those strategies would address themselves to the special financing conditions of those regions, the construction and designs for rural electrification process as well as a project control mechanism that would entail coordinating relevant projects to mitigate losses that would emanate from such projects.

In order for the full benefits of energy access initiatives to be realized, governments have critical roles to play in harmonizing all developmental sectors. Shrestha and Jiwan, (2015) argued that a response to energy access challenges that is driven by demand is able to facilitate a clear understanding of the definite development priorities that the energy sector would be able to satisfy. This would facilitate the process that would be utilized to develop robust demand for energy services that would be critical in underpinning the sustainability of initiatives made in energy access. The process of exploiting synergies in energy sector and establishing linkages between electricity supply and developmental demands for other sectors require well-coordinated interaction between various stakeholders. In the current study it is against these arguments that the study attempted to evaluate the effect of project planning strategy on the execution of energy access projects in underserved counties in Kenya. Planners and policy makers with the help of civil societies and private sector may be able to develop solutions that address themselves to issues related to quality of supply and affordability that most of the times impede access to electricity services even in the presence of effective technologies for service delivery. . It is against these arguments that the article sought to determine the influence of project planning strategy on the implementation of energy access projects in underserved counties in Kenya.

\section{Objective of the Study}

The objective of the study was to examine the extent to which project planning influence implementation of rural energy access projects in underserved counties in Kenya,

\section{Hypothesis of the Study}

The following hypothesis was tested:

1. $\mathrm{H}_{0}$ : Project planning does not significantly influence the implementation of rural energy access projects in underserved counties in Kenya.

2. $\mathrm{H}_{1}$ : Project planning significantly influence the implementation of rural energy access projects in underserved counties in Kenya. 
Avedi, E. K., Mulwa, A. S., \& Kyalo, D. N. (2020) Influence Of Project Planning Strategy On Implementation Of Energy Access Projects In Underserved Counties In Kenya. Advances in Social Sciences Research Journal, 7(4) 335-350.

\section{LITERATURE REVIEW}

Project planning variables such as policy formulation, building capacity and integrating energy access with development programs are key variables that can accelerate energy access. Policy formulation plays a major role in fostering the expansion of a market that attracts private participation. Policies must be flexible in design to accommodate the full range of actors. Policy clarity and consistency are crucial to successful projects that enable a stable, sustainable market sector for SMEs, attract private investment to energy access efforts, and remove barriers to innovative business models. Proper project planning strategies can create incentives and streamline regulations to stimulate a new energy access market, attracting private enterprises and financing. This can leverage scarce government resources to provide more energy services to more citizens more quickly (Singer, 2014).

According to IEA, (2011), access to energy is essential for human life since increasing electricity availability contributes to improved social development and faster economic growth. Access to energy has a direct impact on health, education, life expectancy, child mortality and contributes to income generation and employment. Developed countries enjoy wealth and economic prosperity partly because of their unrestricted access to electricity, while most developing countries are struggling to increase access for their populations. At the end of 2011 over 1.3 billion people had no access electricity, 95\% of these lived in Sub-Saharan Africa or South-East Asia and 84\% of them live in rural areas.

Under normal circumstance, governments develop policies with a view to pursue social goals together with address failures in societies so that they can promote economic efficiency (Kaiser and Ahlemann, 2010). As a result, such policies are developed with a view to help government distribute or redistribute resources so that there can be fairness in their distribution. However, this should be done at no cost or at minimum cost (Kaiser et al., 2010). Otieno and Graca, (2010) claim that ideal policies that address themselves to project implementation should focus their attention on project effectiveness by ensuring that the processes of implementing projects are set in ways that meet institutional, socioeconomic and regulatory goals of their recipients. Furthermore, good policies should ensure that projects are implemented in cost effective manner and that stakeholders are treated fairly without discriminating some of them (Otieno et al., 2010). Njoki, (2013) claims that they should focus on ensuring that projects are implemented with high levels of integrity so that informed decisions making processes that require public infrastructural projects to base their implementation processes on accurate information and even make sure that basic requirements are adhered to.

Electricity and business regulations that are not specifically designed for off-grid or distributed electricity projects can often hinder or stop these projects. When policymakers are trying to enable a wider range of electricity projects to expand energy access, regulations should be reviewed to ensure they allow flexibility in the types of technology, the types of projects, and in business models. Policies should address appropriate regulation at different sizes of projects and required regulations should be dramatically streamlined to facilitate small projects (Pham and Nguyen, 2011).

Building training mechanisms to develop and retain a skilled workforce to meet these jobs is also critical to a sustainable market. In addition, programs which educate the enabling environment 
from policymakers to utilities to local banks to communities and end users, can support sound decisions and realistic expectations (Hande and Surabhi, 2015). Strategies that focus on the people involved in the market can be as important to the success of that market as the technologies themselves. Building the capacity of businesses at all market levels is critical, including operations, sales and marketing, finance, servicing, research and development, and community involvement. Development programs, often led by ministries of development, health, education, agriculture, and environment among others, can provide a valuable vehicle to implement energy access programs, attract and leverage development-focused funding, and learn from longstanding community programs and partnerships (Terri et al., 2015). For this reason, countries around the world are leading cross-ministerial energy access efforts to alleviate poverty, improve health and education, support greenhouse gas emission reductions, and respond to disasters.

Energy access is a critical element of poverty reduction efforts, and governments are increasingly viewing poverty considering energy challenges. The International Institute for Environment and Development (IIED) has proposed that linked energy access-poverty alleviation efforts can be targeted in relation to levels of poverty. Therefore, programs to support these populations should ultimately focus on providing basic social services, such as energy, health and education (Wilson and Neha, 2014).

With more than 50\% of children in developing countries attending primary schools without electricity, expanding energy access is critical to supporting educational goals and priorities. According to a study by Practical Action (2014) electrification can benefit education by extending operational hours of schools, which can in turn allow more students to be served and encourage smaller class sizes, more preparation, and meeting time for faculty, an alternative study location for students without electricity at home and use of the school for other educational purposes in the evenings. Further, school electrification can support use of technologies, such as computers (often critical for professional advancement), provision of meals to students, and improved classroom work environments through temperature control. Ultimately, improving education also supports income generation, which can support, in turn, market-based energy access approaches. A report by IEA, (2011) indicated that while energy poverty can indeed be found in urban areas, energy access today is largely a rural problem, with an estimated $84 \%$ of those suffering from energy poverty living in rural areas. In such settings, agriculture, oftentimes subsistence agriculture, is the principal means of livelihood. With existing networks that are set up to operate in rural communities, agricultural ministries and programs are well poised to leverage expertise and resources in partnership with energy access efforts.

\section{Theoretical Framework}

This article is anchored on the Theory of constraints

\section{Theory of Constraints}

The theory started as a scheduling aid for production and it was developed by Dr. Eliyahu Goldratt back in the 1970s. Back then, it was termed as a time table for optimizing productions; hence, it was adopted into developing a software package referred to as optimized production technology. About a decade later, Goldratt with the help of other people led people into believing that they needed to change their ways of doing things as opposed to tailoring computer programs for automating their old ways of thinking and doing things. This was in relation to the failures experienced under the 
Avedi, E. K., Mulwa, A. S., \& Kyalo, D. N. (2020) Influence Of Project Planning Strategy On Implementation Of Energy Access Projects In Underserved Counties In Kenya. Advances in Social Sciences Research Iournal, 7(4) 335-350.

turnkey package (Davis and Mabin, 2009). Accordingly, Togar and Ramaswami, (2004) suggested that Theory of Constraints aimed at initiating and implementing breakthrough improvements by focusing its attention to constraints that hindered higher performance levels. Accordingly, the theory observes that firms should have at least one constraint that needs to be addressed to optimize outputs. Goldratt and Cox define constraint as every factor or element that hinders systems from performing their duties as they are designed to perform them. That is, it hiders systems from attaining their goals.

According to Sebastiano and Ragnhild (2014), constraints may be classified into four groups. The first group relates to political constraints, which relate to scopes of projects, their visions and missions. The second one relates to technical constraints that relate to technologies, climate, landscape, geological conditions, existing infrastructures and competencies. The third one relate to social constraints, which relate to personal relationships, organizational hierarchies, expected behaviors and codes of conduct. The fourth one relates to administrative constraints, which include project scopes, schedules, contractual agreements and budgets. This theory challenges those in management teams to rethink the way they approach organizational goals, the things they consider to be productive actions and the purposes of cost management.

\section{Conceptual Framework for the Study}

Independent Variable

Dependent Variable

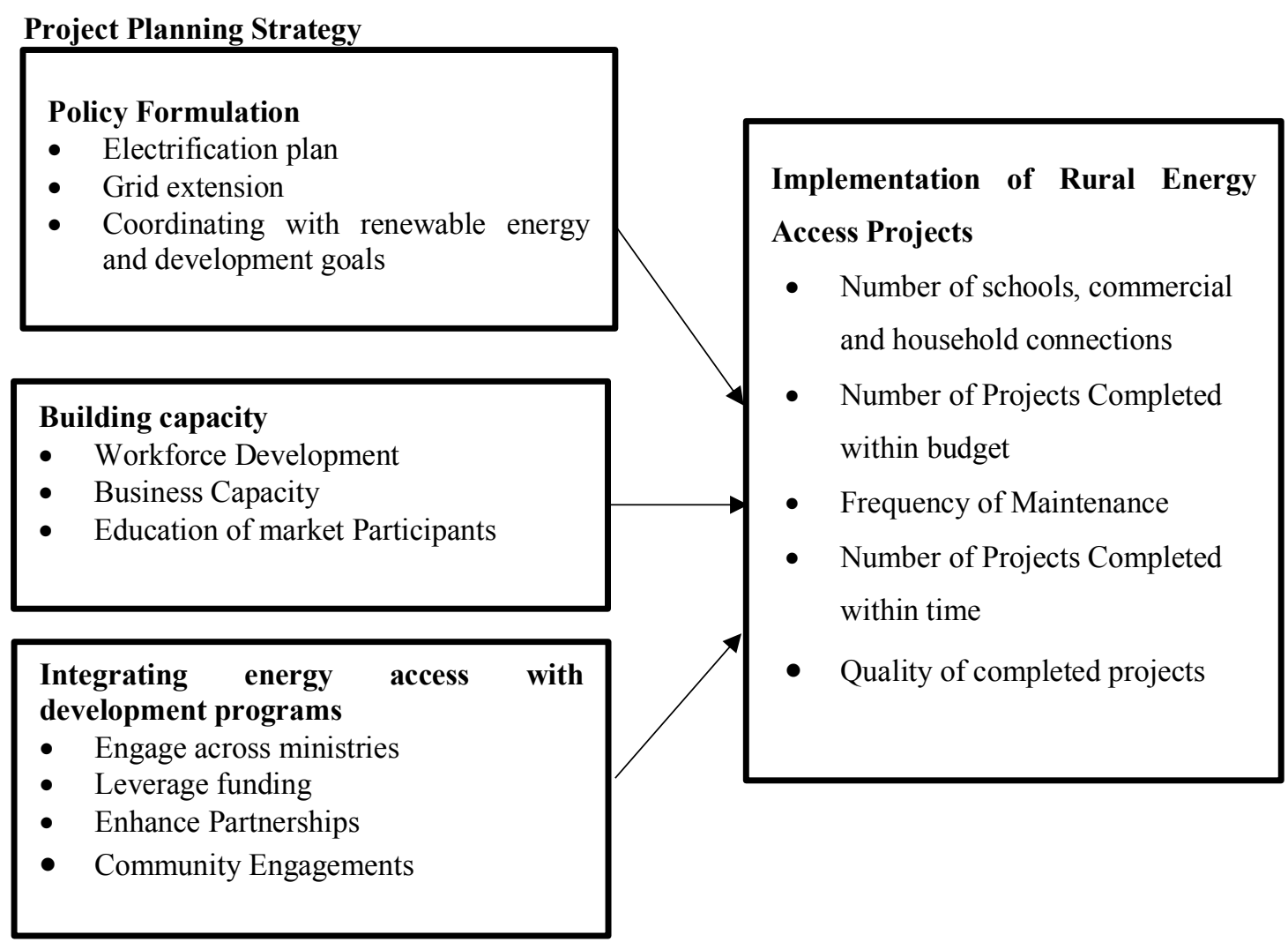

Figure I: Conceptual Framework for the Influence of Project Planning Strategy on Implementation of Energy Access Projects. 


\section{RESEARCH METHODOLOGY}

This section presents aspects of research methodology that was used to conduct the study. These include research paradigm and research design, target population, sample size and sampling procedures, research instruments, data collection procedures and data analysis techniques.

\section{Research Design of the Study}

The study on this article used pragmatism paradigm. Mixed method research looks at many approaches for collecting and analyzing data rather than subscribing to only one way either qualitative or quantitative. Migiro and Magangi (2011) states that mixed methods research encourages researchers to use multiple approaches to collecting and analyzing data within a single study, recognizing the limitations of using a single method. In this article, quantitative data was collected using structured questionnaires whilst qualitative data was collected using interview schedules and observation guide.

\section{Target Population of the Study}

The unit of analysis was households, commercial centers, schools, hospitals and Project managers of the key organizations involved in rural energy access sector projects. The projects were in 14 counties under equalization fund and spread out in the 14 counties in underserved counties in Kenya. The target population was 5,604 respondents drawn from the 6 service territories based on county allocations derived from scale of challenge (un-electrified population and community facilities), poverty index and population density to achieve greatest impact with limited resources, deliver services where the need is the largest, consider additional costs due to low population density and consider principles of equity such that all counties should benefit in a similar manner. Such a division allows economies of scale in procurement and elicits private sector contractors to be present in these undeserved counties over a long term.

\section{Sample Size}

Sample size that was used for the study was obtained using Slovin's formula denoted by the population size and the acceptable margin error of 0.05 as indicated in the following formula:

Where:

$$
\text { Sample size }(\mathrm{n})=\frac{\mathrm{N}}{\left(1+\mathrm{Ne}^{2}\right)}
$$

$\mathrm{n}=$ Number of samples

$\mathrm{N}=$ Population size

e = Margin of error / error margin

Calculating the sample size gives;

$$
\begin{gathered}
\mathrm{n}=\frac{5,604}{\left(1+5,604 \times 0.05^{2}\right)} \\
=373
\end{gathered}
$$

Hence sample size for the study was 373 respondents. The allocation of a sample into the strata was done using Neyman allocation formula. The purpose of this method was to maximize sample survey precision from the calculated sample size. With Neyman allocation the sample size for stratum is as shown in Table I. 
Avedi, E. K., Mulwa, A. S., \& Kyalo, D. N. (2020) Influence Of Project Planning Strategy On Implementation Of Energy Access Projects In Underserved Counties In Kenya. Advances in Social Sciences Research Iournal, 7(4) 335-350.

\section{Table I: Sample Size Calculation for the Study}

\begin{tabular}{|c|c|c|c|c|}
\hline County & Lot Number & $\begin{array}{l}\text { Number of } \\
\text { Projects }\end{array}$ & $\begin{array}{c}\text { Target } \\
\text { Population }\end{array}$ & $\begin{array}{c}\begin{array}{c}\text { Number of } \\
\text { Rampled per Lot }\end{array} \\
\begin{array}{c}\mathbf{n}_{\mathrm{h}}=\left(\frac{N_{\mathrm{h}}}{\mathrm{N}}\right) \times \mathrm{n}=(1380 / 5,604) \\
* 373=92\end{array}\end{array}$ \\
\hline West Pokot & \multirow{2}{*}{1} & \multirow{2}{*}{6} & \multirow{2}{*}{1,380} & \multirow{2}{*}{92} \\
\hline Turkana & & & & \\
\hline Marsabit & \multirow{3}{*}{2} & \multirow{3}{*}{3} & \multirow{3}{*}{660} & \multirow{3}{*}{44} \\
\hline Samburu & & & & \\
\hline Isiolo & & & & \\
\hline Mandera & \multirow{2}{*}{3} & \multirow{2}{*}{6} & \multirow{2}{*}{1,074} & \multirow{2}{*}{71} \\
\hline Wajir & & & & \\
\hline Garissa & \multirow{3}{*}{4} & \multirow{3}{*}{4} & \multirow{3}{*}{880} & \multirow{3}{*}{59} \\
\hline Tana River & & & & \\
\hline Lamu & & & & \\
\hline Kilifi & \multirow{2}{*}{5} & \multirow{2}{*}{3} & \multirow{2}{*}{690} & \multirow{2}{*}{46} \\
\hline Kwale & & & & \\
\hline Taita Taveta & \multirow{2}{*}{6} & \multirow{2}{*}{4} & \multirow{2}{*}{920} & \multirow{2}{*}{61} \\
\hline Narok & & & & \\
\hline \multicolumn{2}{|c|}{ Total } & 26 & 5,604 & 373 \\
\hline
\end{tabular}

\section{Sampling Procedures}

The procedure of how the 373 respondents were selected out of the total population of 5,604 was summarized in Table I. The samples size of this study was 373 respondents. In order to collect enough data and information, the study sampling frame was put into clusters and a cluster sampling used to cluster the regions and simple random sampling was used to select respondents as shown in Table I Purposive sampling was used to select key informant interviewees who in this case were project team leaders from the four participating energy players. Thus, in the current study four key project team leaders from the four energy sectors in the study and 6 project site agents/engineers were selected purposively to participate in the in-depth interviews while simple random sampling was used to select respondents from the strata who were given questionnaires to complete.

\section{Research Instruments}

Data was obtained using questionnaires, interview guide and observation. For this study data collected entailed all the responses on the study variables which included project service outsourcing strategy and implementation of energy access projects. Data obtained from the questionnaires was triangulated with the data from the interview guides and the observation guide. The use of various data collection was in tandem with the pragmatism paradigm which allowed the use of various tools.

\section{Data Collection Procedures}

Prior to the commencement of data collection, permission was sought from the University and the National Commission for Science Technology and Innovation (NACOSTI) to ensure adherence to ethical issues in research. Subsequently approvals were sought from the Council of Governors, REA 
headquarters and from Energy access companies. Contact details of all project site personnel and resident managers were obtained from various players. Questionnaires were used in gathering qualitative and quantitative data. Data collection involved a self-administered questionnaire. The researcher used a drop and pick approach to have the questionnaire filled. The researcher personally administered the questionnaires to the respondent's residents to ensure the right data was collected from the respondents and on time. Therefore, the respondents had a chance to clarify their queries on the spot and the researcher had an opportunity to motivate respondents to respond to questions. The interview dates were pre-arranged, and it used interview guides. Follow up calls and emails were made to book appointments to seek permission from respondents who took part on the interviews. The researcher engaged research assistants whereby some were residents of the underserved counties. The questionnaires were collected back for analysis with the assistance of the research assistants. The research assistants were inducted on the research ethics and on the research instruments and its administration, interview skills and data recording. An introductory letter for research assistant to collect data on the researcher's behalf was given to the research assistants.

\section{Data Analysis Techniques}

This study produced both quantitative and qualitative data to explain the influence of project service outsourcing strategy exhaustively. Once data collection activity was over, the researcher edited and also tackled the issue of blank responses, coded, categorized and keyed in the data into Statistical Package for Social Sciences (SPSS) program for actual analysis to be done. This exercise was done to check for completeness of that data was collected using the questionnaire. Data analysis techniques employed were simple and multiple regression which resulted to useful information.

The researcher further performed descriptive analysis to measure central and dispersion tendencies of variables using mean, standard deviation, frequencies and percentages which portrayed the relationship that existed between two study variables. Study variables were also tested through inferential analysis which was used to test the hypotheses which was further used to generalize the findings from the sample studied. F-test was carried out to assess the significance of the whole equation or to test best of fit. $\mathrm{R}^{2}$ which refers to coefficient of multiple determinations was also used to show how successful the best of fit was in explaining the variation of the data. In addition to the $\mathrm{R}^{2}$ test, the test of the slope using $\mathrm{t}$ statistic was performed to assess the significance level of the individual regression coefficient of each study variable.

Data triangulation was done so as to strengthen the validity and reliability of the data collected. Data was therefore collected from different participants and different sites of the setting. Data obtained was therefore cross-checked for consistency of specific and factual data items s recorded in the data collection instruments. In the current study, data was analyzed through comparison of qualitative data received from structured questionnaires for clients with qualitative in-depth interviews for site engineers and observation guide by the researcher. Further data obtained from the structured questionnaire was analyzed both descriptively and inferentially. The results were then corroborated with those from the structured in-depth interviews and observation guide.

\section{FINDINGS AND DISCUSSIONS}

The main goal of the article was to establish the extent to which project planning influence the implementation of rural energy access projects in underserved counties in Kenya. Questionnaires 
Avedi, E. K., Mulwa, A. S., \& Kyalo, D. N. (2020) Influence Of Project Planning Strategy On Implementation Of Energy Access Projects In Underserved Counties In Kenya. Advances in Social Sciences Research Iournal, 7(4) 335-350.

were administered to 373 respondents. Out of these 302 of them came back filled while 71 were either incomplete or not at all filled. This represented a response rate of $81 \%$ which is generally representative enough for analysis and generalization of findings to the population. The article findings are in tandem with studies by Babbie (2003) that states that a return rate of $50 \%$ is sufficient to rely on the questionnaire for purposes of analysis. Further he stated that a return rate of $60 \%$ was considered to be good and $70 \%$ was assumed to be excellent for data analysis.

\section{Overall Descriptive Analysis on Project Planning}

Project planning was considered in terms of policy formulation, building capacity and integrating energy access with development programs. The mean and standard deviation of these factors as manifested in rural energy access projects is shown in Table II:

Table II: Mean and Standard Deviation of Project Planning

\begin{tabular}{|c|c|c|c|}
\hline Project planning & $\mathbf{N}$ & Mean (M) & $\begin{array}{l}\text { Standard } \\
\text { Deviation }\end{array}$ \\
\hline Policy Formulation & 302 & 3.64 & 0.800 \\
\hline Building Capacity & 302 & 3.17 & 0.779 \\
\hline $\begin{array}{l}\text { Integrating energy access with development } \\
\text { programs }\end{array}$ & 302 & 3.06 & 0.773 \\
\hline Composite mean & & 3.29 & \\
\hline
\end{tabular}

The findings from Table II show that policy formulation contribute to implementation of energy access projects to a great extent $(\mathrm{M}=3.64, \mathrm{SD}=0.80)$, building capacity to a neutral extent $(\mathrm{M}=$ $3.17, \mathrm{SD}=0.779$ ) and integrating energy access with development programs to a neutral extent $(\mathrm{M}$ $=3.06, \mathrm{SD}=0.773$ ). This implies policy formulation is a vital consideration when energy access projects are being implemented in rural areas in Kenya.

The respondents were asked to comment on some challenges they have encountered when enforcing project planning in the area, a number of different views were given, but the notable ones which appeared to conform to a majority were: Lack of proper knowledge by the locals, lack of coordination between Rural Electrification Authority and the private firms in the area, lack of public participation, poor training skills and language barriers. A citation of these challenges reflects why the mean response was at neutral; or rather they think project planning had a neutral role on implementation of energy access projects in the area.

\section{Correlation Between Implementation of Energy Access Projects and Project Planning}

To establish the direction and magnitude of the relationship between implementation of energy access projects and project planning a correlation analysis was conducted. Project planning is a composite of three indicators; policy formulation, building capacity and integrating energy access with development programs. The findings of the correlation analysis are presented in Table III: 
Table III: Correlation between Implementation of Energy Access Projects and Project Planning strategy

\begin{tabular}{ccccc}
\hline & & $\begin{array}{c}\text { Policy } \\
\text { formulation }\end{array}$ & $\begin{array}{c}\text { Building } \\
\text { capacity }\end{array}$ & $\begin{array}{c}\text { energy } \\
\text { access with } \\
\text { development } \\
\text { programs }\end{array}$ \\
\hline $\begin{array}{c}\text { Implementation of Energy Access } \\
\text { Projects }\end{array}$ & $\begin{array}{c}\text { Pearson } \\
\text { Correlation } \\
\text { Sig. (2- } \\
\text { tailed) } \\
\mathbf{N}\end{array}$ & 0.015 & 0.004 & $.110^{*}$ \\
\hline & *. Correlation is significant at the 0.05 level (2-tailed) & 0.04 \\
\hline
\end{tabular}

From the findings of Table III, all the indicators of project planning are significantly positively correlated with implementation of energy access projects. In terms of magnitude, building capacity is the highest with $r=0.166$ followed by policy formulation at $r=0.14$ and then integrating energy access with development at $r=0.118$. Notably however, all the correlations are weak. Correlation however does not mean causality; therein a regression analysis was conducted to verify if there is a statistical relationship between the indicators of project planning and implementation of energy access projects.

Inferential Analysis of Influence of Project Planning on Implementation of Rural Energy Access Projects in Underserved Counties in Kenya.

The following hypothesis was tested using simple regression model to satisfy the objective.

1. $\mathrm{H}_{0}$ : Project planning does not significantly influence the implementation of rural energy access projects in underserved counties in Kenya.

2. $\mathrm{H}_{1}$ : Project planning significantly influences the implementation of rural energy access projects in underserved counties in Kenya.

The mathematical model that was used for testing the null hypothesis was as follows:

Implementation of rural energy access projects $=\mathrm{f}$ (project planning)

$$
\mathrm{Y}=\mathrm{f}\left(\mathrm{X}_{1}, \boldsymbol{\varepsilon}\right) ; \mathrm{Y}=\beta_{0}+\beta_{1} \mathrm{X}_{1}+\boldsymbol{\varepsilon}
$$

Where $Y=$ Implementation of rural energy access projects; $X_{1}=$ Project planning; $\beta_{0}=$ Constant term; $\beta_{1}=$ Beta Coefficient; $\boldsymbol{\varepsilon}=$ Error term

The findings are as presented in Table IV. 
Avedi, E. K., Mulwa, A. S., \& Kyalo, D. N. (2020) Influence Of Project Planning Strategy On Implementation Of Energy Access Projects In Underserved Counties In Kenya. Advances in Social Sciences Research Iournal, 7(4) 335-350.

Table IV: Implementation of Energy Access Projects and Project Planning Model Summary

\begin{tabular}{ccccc}
\hline Model & R & R square & $\begin{array}{c}\text { Adjusted R } \\
\text { Square }\end{array}$ & $\begin{array}{c}\text { Std. Error of the } \\
\text { Estimate }\end{array}$ \\
\hline 0.206 & 0.042 & 0.033 & 3.738
\end{tabular}

a. Predictors: (Constant) PF, BC, IE

\begin{tabular}{|c|c|c|c|c|c|}
\hline \multicolumn{6}{|c|}{ ANOVA } \\
\hline Model & $\begin{array}{l}\text { Sum of } \\
\text { squares }\end{array}$ & Df & Mean Square & $\mathbf{F}$ & \\
\hline Regression & 184.4 & 3 & 61.462 & 4.399 & 0.005 \\
\hline Residual & 4163.1 & 298 & 13.970 & & \\
\hline Total & 4347.5 & 301 & & & \\
\hline
\end{tabular}

a. Dependent Variable: Implementation of Energy Access Projects

b. Predictors: (Constant) PF, BC, IE

\begin{tabular}{cccccc}
\hline \multicolumn{7}{c}{ Coefficients } \\
\hline Model & $\begin{array}{c}\text { Unstandardized } \\
\text { Coefficients }\end{array}$ & $\begin{array}{c}\text { Standardized } \\
\text { Coefficients }\end{array}$ & \\
\hline & B & Std. Error & Beta & t & Sig. \\
(Constant) & 21.401 & 2.079 & & 10.292 & 0 \\
Policy Formulation & 0.2 & 0.119 & 0.101 & 1.685 & 0.093 \\
Building Capacity & 0.243 & 0.135 & 0.112 & 1.803 & 0.072 \\
Integrating Energy & 0.204 & 0.144 & 0.084 & 1.42 & 0.157
\end{tabular}

Dependent Variable: Implementation of Energy Access Projects

Findings in Table IV were further analyzed for goodness of fit and tests of coefficient of determination and test of the slope $(\beta)$ were performed on the model. The outcome was that the test of coefficient of determination was $\mathrm{R}^{2}=0.042$ and $\mathrm{r}=0.206$, an indicator that generally project planning is weakly correlated with implementation of energy access projects. The $\mathrm{R}^{2}=0.042$ was the coefficient of determination for this model and it depicted that project planning explained 4.2 $\%$ of variations in implementation of energy access projects in underserved counties in Kenya. The remaining $95.8 \%$ of variations in implementation of energy access projects in underserved counties remained unexplained and were explained by other variables other than project planning that were not captured in this model. In terms of individual indicators of project planning, both policy formulation and building capacity are statistically significant at $10 \%$ level of significance, since for policy formulation $\mathrm{p}=0.093<0.1$ and for building capacity $\mathrm{p}=0.072<0.1$.

The $\beta$ coefficient test of best of fit on the significance of every individual predictor variable on the independent variable was carried out. The findings as per Table IV on the nature of the relationship between the individual variables using the Beta coefficients depicted that all the indicators apart from integrating energy access projects 0.084 , are not statistically significant at $10 \%(p=0.157)$ 
level of significance or less. Policy formulation Beta coefficient of 0.101 is statistically significant at $10 \%(p=0.093)$ level of significance implying there is a positive significant relationship between policy formulation and implementation of energy access projects. The coefficient building capacity 0.112 is also statistically significant at $10 \%(\mathrm{p}=0.072)$ level of significance implying also that building capacity has a positive statistically significant influence on implementation of energy access projects. In terms of the comparison the variable building capacity seem to influence implementation of access projects more than policy formulation.

The overall F statistic of $F=4.399(p=0.05)$ is statistically significant since $P=0.000<0.05$. This was an indication that there was a statistical relationship between project planning and implementation of rural energy access projects in the underserved counties in Kenya. Therefore, the article rejected the first null hypothesis which states that: $1 . \mathrm{H}_{0}$ : Project planning does not significantly influence the implementation of rural energy access projects in underserved counties in Kenya. These findings implied that project planning had a significant influence on the implementation of rural energy access projects in underserved counties in Kenya.

Using the statistical findings in Table IV, the regression model arising from this analysis was as follows:

Where;

$$
\mathrm{Y}=21.401+0.2 \mathrm{PF}+0.243 \mathrm{BC}+0.204 \mathrm{IE}
$$

Y = Implementation of Energy Access Projects; PF = Policy Formulation; $\mathrm{BC}=$ Building Capacity; IE = Integrating Energy

The findings on the influence of project planning strategy on implementation of energy access projects in underserved counties in Kenya are similar to study findings by Singer (2014) who established that proper project planning strategies can create incentives and streamline regulations to stimulate a new energy access market, attracting private enterprises and financing. This can leverage scarce government resources to provide more energy services to more citizens more quickly. He further argued that Governments can collaborate with stakeholders to understand their individual market needs and thus policy formulation plays a major role in fostering the expansion of a market that attracts private participation. Policies must be flexible in design to accommodate the full range of actors. Policy clarity and consistency are crucial to successful projects that enable a stable, market sector for SMEs, attract private sustainable investment to energy access efforts, and remove barriers to innovative business models. Findings obtained from respondents on policy formulation concurs with study findings by Macharia and Ngugi (2014) while studying the determinants of successful completion of power projects in Kenya power and lighting company who noted that government policies on mega projects plays a greater role as it influences the size, structure, conduct and performance of the government entity during implementation process. These article findings are in line with a study by Njoki, (2013) who asserts that policies should aid project implementation by upholding the integrity of the project to ensure informed decision making which requires public infrastructure projects to base their implementation on accurate information and ensure basic requirements are met.

Considering building capacity, article finding by Hande and Surabhi (2015) found out that strategies that focus on the people involved in the market can be as important to the success of that market as 
Avedi, E. K., Mulwa, A. S., \& Kyalo, D. N. (2020) Influence Of Project Planning Strategy On Implementation Of Energy Access Projects In Underserved Counties In Kenya. Advances in Social Sciences Research Journal, 7(4) 335-350.

the technologies themselves. Building the capacity of businesses at all market levels is critical, including operations, sales and marketing, finance, servicing, research and development, and community involvement. In the article, the interviews conducted established that building capacity was a major indicator that respondents viewed as most valued to them as it will ensure sustainability of the implemented projects. This was greatly supported by a study on off grid energy access by Chaurey and Kandpa (2010) established that when off-grid energy access is approached on a project-by-project basis, without developing the domestic capacity to support the market, the projects are not supported in the long term and the market is not sustainable. This brings concerns that these energy options are not a durable or worthy of investment. A study by (Terri et al., (2015) asserted that development programs, often led by ministries of development, health, education, agriculture, and environment among others, can provide a valuable vehicle to implement energy access programs, attract and leverage development-focused funding, and learn from longstanding community programs and partnerships. For this reason, they argued that countries around the world are leading cross-ministerial energy access efforts to alleviate poverty, improve health and education, support greenhouse gas emission reductions, and respond to disasters. The findings obtained from the interviews established that integrating energy access received a fair rating as most respondents agreed on the awareness of other ministries that supported energy access in their various counties and that there was a fair representation in collaboration.

The findings however did not conform to the study findings by Tomas \& Sanchez, (2013) who studied the influence of economic poverty and lack of political will on electricity access whose results showed that that economic poverty and lack of political will as two important factors influencing the electricity access to rural households. Overall the findings were largely synonymous with the expectations of the study.

\section{CONCLUSION AND RECOMMENDATIONS}

The research objective sought to examine the extent to which project planning influence implementation of rural energy access projects in underserved counties in Kenya. Indicators for project planning strategy were adopted form previous studies and included in the research instrument. The indicators for project planning strategy were policy formulation, building capacity and integrating energy access with development programs. Descriptive statistics showed that the dominant indicator was policy formulation, followed by building capacity and lastly by integrating energy access with development programs. This implies policy formulation is a vital consideration when energy access projects are being implemented in rural areas in Kenya. However, the uptake of project planning strategy indicators by energy access companies including building capacity, integrating energy access with development programs and policy formulation could be explained by some of the following challenges that respondents noted: lack of proper knowledge by the locals, lack of coordination between Rural electrification authority and the private firms in the area, lack of public participation, poor training skills and language barriers.

A citation of these challenges reflects why the mean response was at neutral; or rather they think project planning had a neutral role on implementation of energy access projects in the area. The respondents were further asked to comment on some suggestions that they could propose to handle the challenges of enforcing project planning strategy in the areas. Close to all the respondents cited training as the main aspect or suggestion to enhance project planning while another set of respondents suggested that there should be a lot of involvement of the local community in the 
planning strategy, perhaps to enhance cooperation. The findings from inferential statistics indicated that all the indicators of project planning are significantly positively correlated with implementation of energy access projects. In terms of magnitude, building capacity is the highest with $r=0.166$ followed by policy formulation at $r=0.14$ and then integrating energy access with development at $r=0.118$. The overall $F$ statistic of $F=4.399$ is statistically significant since $P=$ $0.000<0.05$. This is an indication that there is a statistical relationship between project planning and implementation of rural energy access projects in the Kenya. Due to this, the null hypothesis that was being tested was rejected and concluded that project planning had a significant influence on the implementation of rural energy access projects in underserved counties in Kenya. This implies that energy access stakeholders should come up with project planning strategies in terms of policy formulation, building capacity and integrating energy access with development programs. There is therefore, need to develop clear project planning strategies in order to accelerate rural electrification in underserved counties.

The article established that project planning has an influence on the implementation of rural energy access projects in underserved counties in Kenya. This therefore implies that energy access companies should embrace policy formulation, building capacity and integrating energy access with development programs so as to improve implementation of rural energy access projects in underserved counties in Kenya and also to enhance satisfaction of all stakeholders. The sustainability of the energy projects in this article was mainly driven by both local concerns and national policy. This means that the choice and scale of projects should reflect local opportunities; in other words, mainly oriented to serve local demand. Staff who will be appointed to the project implementation units for energy access project, implementing units and other sections which will be responsible for coordinating activities across the company for managing sub-projects for the purpose of maintaining a formative monitoring system throughout the project to assess the quality of implementation, use of funds, and impacts should have the necessary skills in sustainability of the implemented projects. Daily project operation should be managed by local communities in the form of cooperatives and other forms of intermediate institutions or community foundations.

\section{References}

[1]. African Development Bank Group AfDB (2012). Evaluation of Quality Assurance across the Project Cycle of the African Development Bank Group (2012-2017); Synthesis Report. Private Sector Operations Business Manual.

[2]. Babbie, E., (2003). Survey Research Methods. Belmont, California: Wadsworth Publishing Company.

[3]. Chaurey, A., \& Kandpal, T.C., (2010). A techno-economic comparison of rural electrification based on solar home systems and PV microgrids. Energy Policy 38, 3118-3129.

[4]. Davies, J., Mabin, V.J., \& Balderstone, S.J. (2005). The Theory of Constraints: a methodology apart - a comparison with selected OR/MS methodologies. The International Journal of Management Science, 33(6), 506-524.

[5]. Hande, H., \& Surabhi, R., (2015). Effective Leapfrogging to Decentralized Energy Access. Global Energy Affairs.

[6]. IEA., (2014). World Energy Investment Outlook Special Report 2014: International Energy Agency of the Organization of Economic Co-operation and Development (OECD), Paris.

[7]. IEA., (2011). Energy for All: Financing Access for the Poor. Special early excerpt of the World Energy Outlook 2011.

[8]. Kaiser, M. G., \& Ahlemann, F. (2010). Measuring Project Management Information SystemsSuccess:

Towards a Conceptual Model and Survey Instrument.20 - 2010 
Avedi, E. K., Mulwa, A. S., \& Kyalo, D. N. (2020) Influence Of Project Planning Strategy On Implementation Of Energy Access Projects In Underserved Counties In Kenya. Advances in Social Sciences Research Iournal, 7(4) 335-350.

[9]. Macharia, S., \& Ngugi, K., (2014). Determinants of successful completion of power projects in Kenya Power and Lighting Company. International Journal of Social Sciences and Entrepreneurship, 1 (12), $\quad$ 570-580.

[10]. Maithani, P.C., \& Gupta, D., (2015). Achieving Universal Energy Access in India, New Delhi: SAGE.

[11]. Migiro, S. O., \& Magangi, B. A. (2011). Mixed Methods: A Review of Literature and the Future of the New Research Paradigm. African Journal of Business Management, 5(10), 3757-3764.doi: 10.5897/AJBM09.082.

[12]. Njoki, M. N., (2013). The role of Project Management Information Systems towards the success of a Project: The case of Construction Projects in Nairobi Kenya. International Journal of Academic Research in Business and Social Sciences.HR MARS, Vol.3, No.9, ISSN: $2222-6990$

[13]. Otieno, K., O., Apida, M., Eric, O., N, Graca, A. (2010). Factors Influencing Fire Stations Response to Disasters: A case of Kenya. International Journal of Disaster Management and Fire Engineering.Vol. 3, Issue No.2, ISSN: $2221-6799$.

[14]. Pham, K.T., Nguyen, M. B., \& Nguyen, H. D., (2011). Energy Supply, Demand and Policy in Vietnam, with Future Projections, Energy Policy, Vol. 39, pp. 6814-6826.

[15]. Practical Action, (2014). Poor People's Energy Outlook 2014: Key Messages on Energy for Poverty Alleviation. Rugby, UK: Practical Action Publishing.

[16]. Republic of Kenya, (2017). Kenya Off-Grid Solar Access Project for Underserved Counties: Resettlement plan Vol. $2 . \quad$ http://documents.worldbank.org/curated/en/194591490351167867/Annexes

[17]. Republic of Kenya, (2013). Updated least cost power development plan study period: 20112031.http://www.renewableenergy.go.ke/downloads/studies/LCPDP- 2011- 2030- Study.pdf

[18]. Sebastiano, L., \& Ragnhild, K., (2014). Constraint-Shattering Practices and Creative Action in Organizations. European Group for Organizational Studies DOI: 10.1177/0170840613517597

[19]. Shrestha, R. M., \& Jiwan, S. A., (2015). Sustainable Energy Access Planning: A Framework. Mandaluyong City, Philippines: Asian Development Bank

[20]. Singer, C.E., (2014). Decentralized Energy Products and Services: Off-Grid Enterprises. Background paper for the 1ST Meeting of the SE4All Energy Access Committee. 28 April 2014.

[21]. Terri, W., Neha, R., Sean, E., Sadie, C., \& Tim, R., (2015). Policies to Spur Energy Access.: National Renewable Energy Laboratory.

[22]. Togar, M. S., Alan, C. W., \& Ramaswami, S., (2004). Applying the Theory of Constraints to Supply Chain Collaboration. International Journal of Project Management, 9 (1), 23-29.

[23]. Tomas, T., \& Sanchez, T. (2013). Rural electrification: The role of the public sector and collective action on electricity access for the poor in Sub-Saharan Africa; Practical Action; UK, 2013.

[24]. Wamukonya, N., (2013). Power sector reform in developing countries: mismatched agendas. Energy Policy, 31(12), 1273-1289.

[25]. Wilson, E., Neha, R., \& Sara, B., (2014). Sharing the Load: Public and Private Sector Roles in Financing Pro-Poor Energy Access. London: International Institute for Environment and Development. 